\title{
Teologiczna interpretacja przemian w sferze pracy. Podejście Ewangelickiego Kościoła w Niemczech ${ }^{2}$
}

Zachodzące w świecie gwałtowne przemiany, oznaczane przez takie procesy jak cyfryzacja, globalizacja rynków czy postępujące rozwarstwienie technologiczne, by wymienić tylko niektóre, dotykają wszystkich sfer życia ludzkiego. Liczni autorzy w swych diagnozach przekonują, że transformacja, przed którą stoimy, nie oznacza jedynie progresywnej kontynuacji procesu, który rozpoczął się wcześniej, ale jest rewolucją otwierającą nową epokę w dziejach świata, nieporównywalną z tym, co było wcześniej. Nawet jeżeli takie wypowiedzi jawią się jako retoryczny zabieg mający przyciągnąc uwagę czytelników, to jednak ich skala i zasięg nie pozwalają, aby jedyną reakcją na nie było wzruszenie ramionami. Przyszłość jawi się jako nieprzenikniona - i to pomimo ciągłych dążeń do jej kolonizacji (stosując termin Anthony'ego Giddensa).

Jednym z głównych motywów rozważań w ekonomii, socjologii czy polityce społecznej jest przyszłość ludzkiej pracy w kontekście tych przemian. W debacie naukowej i publicystycznej raz po raz pojawiają się opracowania uaktualniające dawne pojęcia dotyczące pracy, przywołujące pierwotne tęsknoty, ale i dostrzegające zupełnie nowe zagrożenia. Dyskusje te toczą się między nadziejami na przyszłość pozbawioną przymusu pracy, wygodną i umożliwiającą człowiekowi twórcze wykorzystanie zdolności, ostatecznie żegnając marksowską alienację, a lękiem przed wizją pracy będącej przywilejem wąskiej grupy potrafiącej sprostać wymaganiom postępu technologicznego i pogrążeniem się reszty społeczeństwa w gnuś-

${ }^{1}$ Piotr Kopiec - dr hab., prof. KUL, Instytut Nauk Teologicznych KUL, Katedra Teologii Protestanckiej, e-mail: piotr.kopiec@kul.pl, ORCID: 0000-0002-0581-0737.

2 Artykuł został opublikowany w ramach projektu finansowanego przez Narodowe Centrum Nauki, nr 2018/31/B/HS1/01254. 
ności, zarówno przymusowej, jak i aprobowanej. Do tych punktów granicznych dochodzą jeszcze zagadnienia stopniowej utraty przez człowieka kontroli nad postępem technologicznym, przed momentem technologicznej osobliwości.

Już choćby takie krótkie wprowadzenie w temat pozwala uzmysłowić sobie, jak bardzo jest potrzebne nowe określenie wartości i norm, które pozwalają człowiekowi zorientować się w często kompletnie nowej sytuacji pracy, a mówiąc jeszcze szerzej, jak bardzo świat potrzebuje nowej kultury pracy. Orientacja ta odnosi się przy tym zarówno do okoliczności życiowych, w których znajduje się człowiek, jak i do oceny działań politycznych dotyczących całego społeczeństwa. W kontekście nowej sytuacji bardzo potrzebny jest głos Kościoła, zarówno w określaniu porządku społecznego, jak i pomagający ludziom odnajdować swoje powołanie i drogi samorealizacji w świecie gwałtownie zmieniających się warunków ekonomicznych i technologicznych.

Do globalnej dyskusji na temat pracy, jej znaczenia i funkcji we współczesnym świecie od wielu lat aktywnie włącza się Ewangelicki Kościół w Niemczech (Evangelische Kirche in Deutschland, EKD) przede wszystkim na dwa sposoby: przedstawiając w dokumentach (tzw. memorandach, Denkschriften) chrześcijańską interpretację aktualnych wyzwań wynikających z przemian w społeczeństwie, gospodarce i technologii oraz prowadząc różne grupy i zespoły eksperckie, które na bieżąco kształtują ewangelicką refleksję dotyczącą tematu. Kościół dąży do wyjaśniania i promowania systemowej wizji społeczeństwa opartej o reformacyjne nauczanie o zawodzie-powołaniu. Teologowie EKD niezmiennie dostrzegają potencjał w ewangelickiej etyce powołaniowej, którą widzą jako nadającą znaczenie oraz strukturę działaniom i relacjom społecznym, a także ekonomicznym. Jawi się to jako szczególnie ważne w świecie gwałtownie się zmieniającym i przez to niestabilnym, tym bardziej, że refleksja Kościoła poparta jest rzetelną analizą wykorzystującą aktualne koncepcje ekonomiczne, socjologiczne i polityczno-społeczne.

Artykuł ma na celu prezentację ewangelickiej koncepcji pracy w perspektywie wyłaniania się nowego porządku ekonomiczno-społecznego i tzw. czwartej rewolucji przemysłowej. Pokazuje, jak teologowie EKD adaptują reformacyjne nauczanie społeczne do bieżących okoliczności i dowodzi, że Kościół ewangelicki dostrzega potrzebę kształtowania systemowej koncepcji obejmującej zarówno modele stosunków pracy, jak i modele edukacji. Refleksja teologiczna EKD zmierza przede wszystkim do sformułowania aksjologicznego fundamentu, na którym mogą oprzeć się strategie polityczne czy społeczne. Przypomnienie teologicznego znaczenia pracy jako powołania jest ważnym czynnikiem tego fundamentu. Realizacja zamierzenia zakłada analizę wybranych tekstów Kościoła osadzoną w kontekście zwięzłego nakreślenia głównych punktów bieżących przemian technologicznych, ekonomicznych i społecznych. 


\section{Czwarta rewolucja przemysłowa}

Refleksja społeczna stale korzysta $\mathrm{z}$ różnych typologii jako narzędzi heurystycznych. Do takich należy również periodyzacja rozróżniająca cztery skokowe etapy w rozwoju przemysłu, a więc cztery rewolucje przemysłowe. Według tego modelu pierwsza rewolucja przemysłowa pojawiła się około 1780 roku i wynikała z rozwoju maszyn napędzanych parą. Stanowiła przejście z gospodarki rolniczej i manufakturowej do przemysłowej. Druga, umiejscowiona około 1870 roku, nastąpiła po wynalezieniu elektryczności, nabyciu umiejętności wykorzystania ropy naftowej i upowszechnieniu się organizacji produkcji masowej, czego symbolem stała się taśma produkcyjna. Trzecia, której początki lokowano w latach sześćdziesiątych XX wieku, obejmowała pojawienie się technologii cyfrowej, rozwój elektroniki, komputerów czy telefonii komórkowej, a także automatyzację produkcji i rozwój nowoczesnych środków komunikacji i bankowości. Pomiędzy poszczególnymi etapami istnieją zależności cechujące się ambiwalencją między ciągłością i zerwaniem: $\mathrm{z}$ jednej strony tworzą one pewną sekwencję, w której każdy następny etap prezentuje wyższy poziom innowacji, kumulując potencjał zmian. Z drugiej jednak, o przejściu na kolejny stopień decyduje radykalny przełom związany z wprowadzeniem jakiegoś wynalazku technologicznego, którego przyswojenie po czasie głęboko zmienia porządek ekonomiczny i społeczny.

Dlaczego w takim razie przemiany, które następują w ostatnich kilku latach, oznaczane są przez część autorów jako czwarta rewolucja przemysłowa? Co jest takim przełomem, który wprowadza świat w kolejną epokę? Określenie „,czwarta rewolucja przemysłowa” zostało spopularyzowane przez niemieckiego ekonomistę i założyciela Światowego Forum Ekonomicznego Klausa Schwaba, który nie tylko stwierdził jej istnienie, ale też uznał, że jest ona głęboko odmienna niż poprzednie:

W czwartej rewolucji przemysłowej nie chodzi jednak tylko o inteligentne i połączone ze sobą maszyny i systemy. Jej zakres jest znacznie szerszy. Zachodząc jednocześnie są to fale dalszych przełomów w obszarach sięgających od sekwencjonowania genów do nanotechnologii, od odnawialnych źródeł energii do informatyki kwantowej. To właśnie fuzja tych technologii i ich interakcja pomiędzy sferami fizyczną, cyfrową oraz biologiczną, czynią czwartą rewolucję przemysłową fundamentalnie inną niż poprzednie rewolucje ${ }^{3}$.

Dowodząc swojej tezy o jakościowej różnicy pomiędzy rewolucją, której obecnie doświadczamy, a poprzednimi, Schwab wyodrębnia przynajmniej trzy

${ }^{3}$ K. Schwab, The Fourth Industrial Revolution, Geneva 2016, s. 12. 
jej cechy. Pierwszą jest nie mające precedensu w historii wykładnicze tempo przemian, jakie się na nie składają. Drugą jest fundamentalna zmiana w ekonomii, społeczeństwie, ale też w życiu poszczególnych jednostek, do której prowadzi rozpowszechnienie się technik cyfrowych. Trzecią zaś transformacja całego systemu produkcji, zarządzenia i władzy, która będzie wynikać z zasięgu, w jakim rewolucja ta obejmie społeczeństwa. Niemiecki autor uznaje, że wyłania się świat, którego w tym momencie nie jesteśmy w stanie zrozumieć, ale którego przejawy możemy już teraz odczuć, obserwując obecne zjawiska, świat, który będzie zupełnie inny, niż „wszystko, czego ludzkość wcześniej doświadczyła”.

Niepewna przyszłość, nie dająca ująć się w jakieś odgórne „plany pięcioletnie", skutkuje napięciem pomiędzy nadziejami a zagrożeniami. Taka nieprzejrzystość jutra nie jest oczywiście czymś nowym - od kilkudziesięciu lat narracja kryzysu jest charakterystyczna dla współczesności, jest jej stanem chronicznym $^{5}$ - ale obserwacja czwartej rewolucji przemysłowej wyraźnie wskazuje na główną jej przyczynę, jaką jest rewolucja cyfrowa. Ponownie oddając głos Schwabowi:

Zmiany są tak głębokie, że z perspektywy historii ludzkiej, nigdy nie było okresu czy to tak wspaniałej obietnicy, czy też potencjalnej zagłady. Bieżąca rewolucja technologiczna i cyfrowa, a także wynikająca z niej głęboka i systemowa zmiana, czynią trafnym nadużywane, albo często niewłaściwie używane porzekadło „ten czas jest inny”. Krótko mówiąc, wielkie innowacje technologiczne są na skraju wzniecania doniosłych przemian ${ }^{6}$.

Przekonanie Schwaba podziela wielu innych obserwatorów współczesnych przemian. Można tu przypomnieć choćby Jeremy’ego Rifkina, który w latach dziewięćdziesiątych XX wieku opublikował słynną książkę Koniec pracy (The End of Work) z raczej ponurymi prognozami na kolejne dekady, a dzisiaj z optymizmem spogląda w przyszłość, uznając za rzeczywistą szansę wyrugowania przymusu pracy. Refleksję społeczną zdaje się więc przenikać atmosfera oczekiwania na nowy kształt świata, z innym układem sił politycznych, innym porządkiem gospodarczym, a nade wszystko z innymi formami relacji społecznych, w których stawiany będzie człowiek. Gdyby odwołać się do klasycznej teorii anomii, to kolejne lata będą potęgować trudności wynikające z nieznanego dotychczas tempa przemian: rozluźnianie więzi społecznych, permanentną przebudowę struktury społecznej (o ile w ogóle mówić o jakiejś strukturze), brak

${ }^{4}$ Tamże.

5 A. Giddens, Nowoczesność i tożsamość. „Ja” i spoleczeństwo w epoce późnej nowoczesności, Warszawa 2012, s. 26.

${ }^{6}$ K. Schwab, dz. cyt., s. 14. 
kontroli nad wzrostem gospodarczym i postępem technologicznym z wszelkimi tego negatywnymi skutkami. To, co obserwował Durkheim we współczesnym sobie świecie przyśpieszonej industrializacji, dzisiaj może powtarzać się w spotęgowanym stopniu:

Dzieje się tak w warunkach szybkich przemian gospodarczych, za którymi nie nadąża przebudowa organizacji społecznej i świadomości moralnej. Pozostawieni sami sobie ludzie przestają wiedzieć, co jest możliwe, a co niemożliwe, co sprawiedliwe, co niesprawiedliwe, jakie rewindykacje i nadzieje są uprawnione, jakie zaś idą zbyt daleko, popędy, nie powściągane już przez zdezorientowaną opinię, nie znają już granic, przed którymi powinni się zatrzymać. Wszędzie, od góry do dołu drabiny budzą się pożądania, które nie wiedzą, gdzie ostatecznie się zatrzymać. Nic nie może ich uśmierzyć, gdyż cel, ku któremu się kierują, jest nieskończenie dalej od wszystkiego, cokolwiek dałoby się osiągnąć. Pragnie się nowych rzeczy, przyjemności i wrażeń nieznanych, ale i one tracą cały swój smak $\mathrm{z}$ chwilą, gdy stają się dostępne. W tych warunkach brak sił, aby znieść najmniejsze niepowodzenia ${ }^{7}$.

Powyższy tekst francuskiego klasyka socjologii, pisany wszak 130 lat temu, wciąż jeszcze zaskakuje aktualnością. W przejmujący sposób uzmysławia skalę wyzwań, przed jakimi stoją przede wszystkim instytucje, których celem jest, albo powinno być, określanie, aktualizowanie i nauczanie aksjologicznych fundamentów dla społeczeństwa będącego zdolnym przyswoić sobie tak gwałtownie zmiany.

Kościół Ewangelicki w Niemczech jednoznacznie potwierdza, że taki cel również należy do jego przestrzeni odpowiedzialności. W swym opisie aktualnego stanu rzeczy teologowie $\mathrm{z}$ EKD odwołują się między innymi do Schwaba, ale poszerzają jeszcze katalog czynników przemian. Dobrym przykładem takich diagnoz jest dokument Rady EKD pod tytułem Solidarność $i$ samostanowienie $w$ przemianach świata pracy (Solidarität und Selbstbestimmung im Wandel der Arbeitswelt). W opisie ogólnych tendencji, które kształtują współczesny świat pracy, autorzy wymieniają cyfryzację, globalizację, wzrastającą współzależność rynków oraz międzynarodowy podział pracy. Znaczenie pierwszego $\mathrm{z}$ wymienionych procesów dostrzegają $\mathrm{w}$ przekraczaniu (albo zaciemnianiu) granic czasu i przestrzeni w odniesieniu do produkcji przemysłowej, handlu, usług czy rękodzieła. Ujmowana z tej strony cyfryzacja kompletnie więc zmienia dotychczasowe wymiary ludzkiego działania. Warto wspomnieć, że teologowie z EKD są tutaj blisko refleksji Anthony'ego Giddensa, który rozrywanie czasu i przestrzeni oznaczał jako jedną z cech póź-

\footnotetext{
7 J. Szacki, Historia myśli socjologicznej, t. 1, Warszawa 2012, s. 438n.
} 
nej nowoczesności. Globalizacja jest przedstawiana w perspektywie permanentnego nacisku na przedsiębiorstwa, które stale muszą adaptować się do nowych sytuacji. Współzależność rynków i związane z nią: globalna dostępność kapitału i zasobów oraz obniżające się koszty transportu i komunikacji prowadzą do większej przejrzystości wśród uczestników rynku, a w konsekwencji do wzrastającej konkurencyjności. Jest ona również konsekwencją międzynarodowego podziału pracy.

Uzupełnieniem dla powyższej listy może być zwięzła analiza Ewangelickiej Grupy „Kościół-Gospodarka-Praca” (Evangelischer Verband „Kirche-Wirtschaft-Arbeitswelt") zatytułowana Świat pracy 4.0 (The World of Work 4.0). Autorzy wychodzą od założenia, które niesie na myśl obserwacje o niedostosowaniu tempa przemian kulturowych i społecznych do postępu technologicznego (co ilustruje choćby powyższy tekst Durkheima albo teza opóźnienia kulturowego Williama Ogburna):

W tym momencie, akcent jest położony głównie na rozwój technologiczny, podczas gdy lekceważone są zmiany społeczne i kulturowe powodowane przez cyfryzację, czy to świadomie, czy nieświadomie, czy pośrednio, czy też bezpośrednio8.

Uwagę teologów z EKD można rozszerzać na wiele sposobów - na przykład wskazując na niedostosowanie legislacji, nieujmującej wielu zjawisk tworzonych przez postęp, czy też na absolutyzowanie pewnych wartości bez zwracania uwagi na konsekwencje społeczne (np. wolność w Internecie); jej znaczenie odsyła również do znanej krytyki elity merytokratycznej, jaką formułował Zygmunt Bauman.

W konsekwencji analiza formułuje drugi punkt o konieczności rozwijania takich strategii rozwoju ekonomiczno-społecznego, które będą nieodzownie obejmować poszukiwanie metod etycznego wykorzystywania procesów cyfryzacji. Nie mogą one być przy tym traktowane jedynie jako poboczny motyw towarzyszący rozwiązywaniu konfliktów społecznych. Instytucje polityczne, społeczne czy obywatelskie, również Kościół, muszą postawić sobie pytanie: ,jak chcemy wspólnie żyć" w perspektywie takiej gwałtownej cyfryzacji?

Pytanie to odsyła do kolejnego punktu analizy podkreślającego pogłębiające się podziały społeczne w skali zarówno globalnej i regionalnej. Naturalnie rozwarstwienie zarówno między państwami, jak i wewnątrz państw jest jednym z najczęściej przywoływanych symptomów współczesności, a mass media co jakiś czas prezentują obliczenia pokazujące kumulację światowego bogactwa w rękach coraz węższej elity, a także kurczenie się klasy średniej. Teologowie z EKD koncentrują się tu jednak na intensyfikującej ten podział sile, za jaką

\footnotetext{
${ }^{8}$ Evangelische Kirche in Deutschland, The World of Work 4.0, Hannover 2017, s. 2.
} 
uznają właśnie cyfryzację, która tak napędza monopolizację gospodarki, jak i, wraz z obejmowaniem całej rzeczywistości, tworzy nowe podziały społeczne. $\mathrm{W}$ ten sposób również cyfryzacja powiększa niesprawiedliwość społeczną ${ }^{9}$, dzieląc społeczeństwo na tych, którzy mogą sprostać jej wymaganiom, i tych, którzy z różnych przyczyn są pozbawieni cyfrowych kompetencji. Sytuację tę ilustrują wiele mówiącym tytułem utworu Abby Zwycięzca bierze wszystko (The Winner Takes It All).

Istota tego podziału nie może jednak być sprowadzana do uczestnictwa w czerpaniu ekonomicznych korzyści z rozwoju technologicznego. Jego równie ważnym aspektem jest udział w dystrybucji władzy, a właściwie stopniowa erozja demokracji, która roztapia się w paradygmacie różnych schematów, kategorii i algorytmów legitymizowanych naukowością. Dlatego też członkowie ewangelickiego zespołu podkreślają, że świat bezwzględnie potrzebuje współpracy instytucji państwowych i instytucji społeczeństwa obywatelskiego, włącznie z Kościołami, dla wypracowania strategii politycznych regulujących rozwój technologii i poddających go szerszemu celowi. W przeciwnym razie społeczeństwa mogą popaść w kontrolę przez tych, którzy będą wykorzystywać algorytmy dla własnych korzyści.

Globalny rozwój ekonomiczny i technologiczny ma swoje konsekwencje nie tylko w makroprocesach społecznych odnoszących się do pracy, ale również i w życiu poszczególnych jednostek. Zanika część zawodów, pojawiają się w to miejsce potrzeby nowych umiejętności. Charakterystyczną konsekwencją digitalizacji gospodarki jest zaburzenie dotychczasowego rytmu pracy i uelastycznienie jej warunków. $Z$ drugiej strony pracownicy będą stawiani przed wyzwaniem większej kreatywności w realizacji zadań zawodowych. To zaś narzuca konieczność reorientacji modelów edukacji i uświadamia, jak wielką rolę ma nabycie umiejętności samouczenia się.

Zmiany w sferze pracy obejmują również rodzinę. Nie dotyczy to jedynie przemian w przypisywaniu praw i obowiązków małżonków do danej płci, obejmuje również zniesienie radykalnego podziału między czasem pracy a czasem prywatnym czy czasem domowym. Pochodną tego procesu jest stopniowe odchodzenie od będącego dziedzictwem epoki industrializacji rozróżnienia między pracą zawodową a pracą w domu i pracą opiekuńczą.

Teologowie EKD w swych dokumentach streszczają powszechnie prezentowane diagnozy współczesnych przemian dotyczących natury pracy. Konkludując, warto zaznaczyć, że podobnie jak wielu autorów, dostrzegają konieczność refleksyjnej i systemowej zmiany, której przeprowadzenie będzie należeć do odpowiedzialności poszczególnych instytucji społecznych (również Kościoła), a która przygotuje ludzi na nowe warunki i formy pracy. Stawką jest społeczeń-

\footnotetext{
9 Tamże, s. 4.
} 
stwo bardziej solidarne i sprawiedliwe, które potrafi twórczo wykorzystać możliwości rewolucji technologicznej, a niebezpieczeństwem społeczeństwo rozbite, niezdolne do sprzeciwienia się manipulacji i rzeczywiście zagrożone utratą kontroli nad postępem w technologii.

\section{Teologiczne inspiracje $w$ formowaniu nowego paradygmatu pracy}

W dokumencie Solidarität und Selbstbestimmung teologowie dobitnie stwierdzają, że gwałtowne przemiany w sferze pracy wymagają interpretacji teologicznej, kształtującej społecznoetyczny fundament dla przyszłości w sferze pracy i określają to zadanie przez następujące pytania: jak w świetle wiary chrześcijańskiej określać bieżącą sytuację ludzi pracy, zwłaszcza jeśli weźmie się pod uwagę ambiwalencję rynku i warunków pracy? Pod jakimi warunkami praca może być doświadczana jako wysiłek wspólnotowy? Czy szczególne dziedzictwo protestantyzmu, jakim jest koncepcja pracy jako powołania, jest jeszcze adekwatne we współczesnej sytuacji? Jak takie znaczenie powołania może być dzisiaj społecznie ujmowane i jak oceniamy wzajemne zależności między pracą zarobkową, opiekuńczą i pracą w rodzinie? ${ }^{10}$.

Poszukiwanie odpowiedzi na powyższe pytania prowokuje kwestie będące na jeszcze wyższym poziomie ogólności. Mianowicie, praca ludzka, podobnie jak inne zjawiska i działania człowieka, podlega tradycyjnemu napięciu pomiędzy indywidualizmem i kolektywizmem, między dobrem jednostki a dobrem ogółu. Napięcie to zyskuje jeszcze na intensywności w miarę jak postępująca specjalizacja i zmiany technologiczne wypychają rzesze ludzi z rynku pracy poddanego polityczno-społecznym regulacjom. Pozostawienie tego zjawiska tylko jakiejś samoregulacji mechanizmami rynku skutkowałoby pogłębiającym się podziałem i konfliktem między grupami społecznymi i w perspektywie rozpadem społeczeństwa.

Kościół ewangelicki wielokrotnie podkreślał niebezpieczeństwo polityczno-społecznego leseferyzmu. W swoich dokumentach promuje społeczną gospodarkę rynkową (w ostatnich latach społeczno-ekologiczną) z silnymi instytucjami. Instytucjonalizm głoszony przez teologów wywodzony jest z reformacyjnej koncepcji społecznej i politycznej, której elementami składowymi są: wyraźny podział kompetencji władzy duchownej i władzy świeckiej; koncepcja zawodu-powołania, według której życie chrześcijańskie wymaga rzetelnego wypełniania ról przyporządkowanych człowiekowi w zależności od zajmowanej

${ }^{10}$ Evangelische Kirche in Deutschland, Solidarität und Selbstbestimmung im Wandel der Arbeitswelt. Eine Denkschrift des Rates der Evangelischen Kirche in Deutschland (EKD) zu Arbeit, Sozialpartnerschaften und Gewerkschaften, Gütersloh 2015, s. 49. 
przez niego pozycji w społeczeństwie oraz koncepcja gospodarstwa domowego (Haushalt, oeconomia) jako tzw. trzeciego regimentu, w którym szereg istotnych funkcji społecznych realizuje rodzina. W tle tego nauczania kluczowa jest koncepcja kapłaństwa powszechnego, a patrząc jeszcze ogólniej, pierwotne twierdzenie antropologii biblijnej o Bożym mandacie współtworzenia świata, który dotyczy wszystkich ludzi, bez względu na ich zadania, hierarchie czy dochody ${ }^{11}$.

Niezależnie od kierunków rozwoju teologii protestanckiej oraz wewnętrznych różnic pomiędzy poszczególnymi jej tradycjami, powyższe nauczanie upoważnia do stwierdzenia, że teologia reformacyjna rozwijała systemową koncepcję społeczeństwa. Życie społeczne jest w niej ujęte w system funkcjonalnie zależnych jednostek i instytucji, wśród których kluczowe role spełniają państwo, Kościół i rodzina. Formułując taką opinię, należy mieć oczywiście świadomość problemu adekwatności pojęć i kategorii współczesnej socjologii do szesnastowiecznego kontekstu społecznego i kulturowego. Ponadto nauczanie to nie jest usystematyzowaną teorią, ale jest raczej teologicznym opisem współdziałania między Bogiem a społecznością chrześcijańską w rozwijaniu życia społecznego, jest „hermeneutyką rozróżniającego się współdziałania Boga i człowieka w rzeczywistości świata" ${ }^{12}$. Jest więc podporządkowane teologii, a znaczenie temu systemowi nadaje prawda o usprawiedliwieniu człowieka przez wiarę. „Społeczne” konsekwencje takiego punktu wyjścia zawierają się w przekonaniu, że usprawiedliwiony człowiek jednocześnie wciąż żyje w świecie grzechu. Stąd też, w realizacji królestwa Bożego konieczne jest dwoiste działanie, przedstawiane przez Lutra w postaci nauki o dwóch regimentach: świeckim i duchowym. Ten pierwszy ma przeciwdziałać wszystkiemu, co zakłóca społeczne współżycie, posługując się prawem egzekwowanym przymusem. Drugi ma głosić królestwo Boże, przybliżając ludziom Ewangelię. Można więc powiedzieć, adaptując to nauczanie do teorii funkcjonalnej, że obszarem jego działania będzie kultura, a szczególnie sfera wartości.

Reformacyjna koncepcja polityczno-społeczna jest bez wątpienia teologicznym wariantem przyszłego podejścia funkcjonalistycznego, zwłaszcza w wersji Talcotta Parsonsa. Zresztą amerykański socjolog musiał dobrze poznać nauczanie społeczne reformatorów, choćby thumacząc na język angielski Webera Etykę protestancka. Dla funkcjonalistów celem społecznych działań był ład społeczny, dla Lutra, Kalwina i ich towarzyszy rzeczywistość społeczna była raczej pośrednim etapem na drodze do zbawienia. Ale niezależnie od ostatecznego celu, w obu koncepcjach życie społeczne jest traktowane jako system ustrukturalizowanych współdziałań różnych ról podejmowanych przez jednostki, zarówno indywidu-

11 Tamże, s. 11.

${ }^{12}$ H.-R. Reuter, Grundlagen und Methoden der Ethik, w: Handbuch der Evangelischen Ethik, Hg. W. Huber, T. Meireis, H.-R. Reuter, München 2015, s. 49. 
alnie, jak i grupowo, zgodnie z przypisaną im pozycją. To przekonanie zyskuje jednak na intensywności, jeżeli uzupełni się je o nadmienioną już ewangelicką koncepcję zawodu-powołania.

Powołanie jest z pewnością słowem kluczowym społecznego nauczania reformacji. Wyraźnie podkreślają to teologowie EKD w przywoływanym już kilkukrotnie dokumencie:

Marcin Luter był głęboko przekonany, że wszyscy ludzie są powołani przez Boga do podejmowania aktywnej roli w społeczeństwie, a w szczególności w służbie bliźnim. W takim ujęciu każdy ma jakieś powołanie. Praca każdego ma więc znaczenie i nigdy nie jest bezcelowa. Ideałem chrześcijańskim nie jest niezmordowana aktywność dla samej siebie, ale powszechne, angażujące każdego uczestnictwo w gospodarce, w której praca jest wykonywana jako akt wspólnotowy ${ }^{13}$.

Warto tu przypomnieć, że Luter wiele razy wyrażał przekonanie o powołaniu, które jest udziałem każdego chrześcijanina, jak na przykład w słynnym fragmencie z jednego ze swych wczesnych traktatów Do szlachty chrześcijańskiej narodu niemieckiego:

Szewc, kowal, chłop - każdy ma urząd i zajęcie swego zawodu, a przecież oni wszyscy są w równej mierze poświęconymi kapłanami i biskupami i każdy winien swoim urzędem i swą czynnością być innym pożytecznym i do służby gotowym, by w ten sposób różne czynności wszystkie we wspólnocie ciało i duszę wzmacniały, podobnie jak wszystkie członki ciała służą sobie wzajemnie ${ }^{14}$.

$\mathrm{Na}$ koncepcję zawodu-powołania oczywiście zwrócił uwagę Weber w swym socjologicznym klasyku. Niemiecki socjolog ugruntowywał swoje spostrzeżenie w zbiorze twierdzeń teologii protestanckiej (skrupulatnie odnosząc się do różnic w poszczególnych wyznaniach), wychodząc od nauki o usprawiedliwieniu i obserwacji o kwestionowaniu znaczenia uczynków pobożnościowych w teologii reformacyjnej. Wyraźna afirmacja czynów skierowanych na drugiego i na całą wspólnotę jest wyrażana w wielu pismach Lutra, jak na przykład w jego kazaniu o stanie małżeńskim:

Niczym jest pielgrzymka do Rzymu, niczym do Jeruzalem, do świętego Jakuba. Niczym jest budować kościoły, niczym odprawiać mszę, albo inne tego typu uczynki spełniać, wobec pracy, jaką wykonują rodzice wychowując swoje dzieci.

${ }^{13}$ Evangelische Kirche in Deutschland, Solidarität und Selbstbestimmung..., dz. cyt., s. 6.

${ }^{14}$ M. Luter, Do chrześcijańskiej szlachty niemieckiego narodu o ulepszeniu chrześcijańskiego stanu, seria: „Z problemów reformacji”, t. 6, Bielsko-Biała 1993, s. 76. 
Nie mogą lepiej zasłużyć sobie na niebo, jak tą pracą i gdyby nie wykonywali jej dobrze, podobne byłoby to do niepalącego się ognia, bądź do wody, która nie zwilża ${ }^{15}$.

Przytoczony fragment potwierdza bardzo wysokie znaczenie, jakie Luter przypisuje małżeństwu i rodzinie, ale również pokazuje jego ideał postawy chrześcijanina realizujący się w działaniach na rzecz bliźniego i dobra wspólnego. W tym kontekście Weber zauważa, że w miarę rozwoju teologii reformatora praca zawodowa zaczynała zyskiwać coraz bardziej religijny wymiar. $\mathrm{W}$ pracy zawodowej chrześcijanin spełnia swe powołanie, potwierdza swoją wiarę i manifestuje swoją chrześcijańską postawę ${ }^{16}$.

Koncepcja zawodu-powołania stała się często wykorzystywanym narzędziem w opisie reformacyjnej nauki społecznej. Rzeczywiście, rozważając systemową wizję społeczeństwa, jest ona koniecznym antropologicznym spoiwem, który umożliwia utrzymanie i rozwój systemu społecznego. Nie da się budować spójnego społeczeństwa bez nadawania znaczenia działaniom jednostki, wtedy bowiem do pracy trzeba albo zwodzić obietnicą konsumpcji, albo do niej zmuszać, co jest skuteczne jedynie na krótką metę i zawsze prowadzi do załamania społecznego. Przyjmując, że człowiek ujmuje jako swoje powołanie zadania wynikające z pełnionych ról, reformacyjne nauczanie społeczne prowadzi do równowagi między jednostką a społeczeństwem, wymykając się zarówno indywidualizmowi, jak i kolektywizmowi.

\section{Teologiczny fundament dobrej pracy}

Dokumenty EKD na temat pracy i edukacji pokazują wiele szczegółowych rozwiązań z obszaru polityki społecznej - na przykład naświetlających działanie związków zawodowych, znaczenie układów zbiorowych czy negocjacji w sytuacjach konfliktów społecznych, katalogujących istniejące formy zatrudnienia itd. Są one bez wątpienia ciekawe dla analiz polityczno-społecznych, ekonomicznych czy socjologicznych. Dla teologa jednak bardziej interesujące wydają się drogi, w jakich EKD, wykorzystując teologiczny fundament, określa wartości odnoszące się do pracy i edukacji w perspektywie współczesnych przemian technologicznych.

Ewangelicki Kościół w Niemczech wielokrotnie deklarował, że jednym z kluczowych celów, jakie określają jego istotę, jest kształtowanie przestrzeni

${ }^{15}$ M. Luther, Ein Sermon vom ehelichen Stand, w: Vom ehelichen Leben und andere Schriften über die Ehe, Hg. D. Lorenz, Ditzingen 1997, s. 37.

${ }^{16}$ M. Weber, Etyka protestancka a duch kapitalizmu, Lublin 1994, s. 65. 
aksjologicznej w kontekście gwałtownych zmian zachodzących w świecie. W memorandum Kościól wolności teologowie w następujący sposób ujmowali współczesne okoliczności działania:

We wspólnych wysiłkach musi chodzić o to, aby poprzez nowe formy głoszenia Słowa, kształtowania wspólnoty i kościelne propozycje edukacji reagować na nowe pytania o sens i o wartości, o oparcie i o religię. Oczywiście taka zmiana przychodzi z trudem. Idzie w parze z lękami, troskami i zniechęceniem. W Kościele ewangelickim również odzwierciedla się rozdarcie pomiędzy koniecznością reform a tęsknotą za tym, co było, charakterystyczną dla wszystkich społecznych procesów przemian współczesności. Gdyby Kościół ewangelicki nie dokonał jednak koniecznej zmiany mentalności, zanegowałby decydujące wymagania teraźniejszości i przeoczyłby ważne szanse na przyszłość ${ }^{17}$.

Powyższy cytat można odnieść do stosunku Kościoła do sfery pracy, bowiem również w tym kontekście dostrzega on konieczność zmiany samego siebie, jak i reagowania na nowe wyzwania, właśnie zwłaszcza przez odpowiedź na pytania o wartości i o fundamenty. Można przecież powiedzieć, że praca jest również dzisiaj bardzo często odrywana od wartości, czy to poprzez skupianie się jedynie na jej materialnym celu, czy poprzez uwłaczające godności człowieka warunki pracy. Naturalnie to stwierdzenie jest zdecydowanie bardziej adekwatne, kiedy wyjdzie się poza kontekst niemiecki czy, szerzej, europejski. Praca, w swych przemianach, wciąż potrzebuje określenia przez wartości, by nie stawać się jedynie przymusowym działaniem wpędzającym człowieka w duchowy marazm, zniechęcenie czy apatię. Praca może wreszcie budować społeczną równowagę, jeżeli ugruntowana jest w wartościach, które właściwie określają współzależność między jednostką a społeczeństwem, może też być czynnikiem rozkładającym społeczeństwo, pogłębiającym podziały, tworzącym konflikt, jeżeli od takich wartości jest oderwana.

Określenie tych wartości wyrasta $\mathrm{z}$ teologicznoantropologicznego fundamentu ujmującego człowieka jako Boże stworzenie, obdarzonego wolnością i wezwanego do odpowiedzialności:

Ludzie (...) stworzeni na Jego obraz, są wyzwoleni oraz powołani do dalszego rozwijania Bożego stworzenia we wciąż toczącym się procesie, szczególnie jeżeli chodzi o biblijny mandat jego ochrony. Optymalnie, ludzie podejmują tę pracę jako zawód, w którym mogą rozwijać swoje talenty. Może to jednak następo-

${ }^{17}$ Evangelische Kirche in Deutschland, Kirche der Freiheit. Perspektiven für die evangelische Kirche im 21. Jahrhundert. Ein Impulspapier des Rates der EKD, Hannover 2006, s. 20. 
wać tylko poprzez współpracę z innymi, skoro praca jest czymś wspólnotowym, a ludzie ponoszą dla niej odpowiedzialność w wolności, którą są obdarzeni ${ }^{18}$.

W sformułowaniu pobrzmiewają echa kategorii „wolności odpowiedzialnej”, która w ostatnich latach staje się podstawą etyki społecznej rozwijanej przez Kościół ewangelicki.

Teologowie z EKD wyprowadzają z tej podstawy dwie kluczowe wartości, na których powinna opierać się chrześcijańska interpretacja pracy: solidarność (Solidarität) oraz samostanowienie (Selbstbestimmung). Ich realizacja jest warunkiem kształtowania społeczeństwa, w którym człowiek może poprzez pracę właściwie odpowiadać swojemu powołaniu.

W memorandum cytowanym powyżej znaczenie obu wartości jest przyjęte bez ściślejszego zdefiniowania i opisane raczej sytuacyjnie, w odniesieniu do konkretnej problematyki pracy. Uwaga ta dotyczy zwłaszcza solidarności, która jest ujmowana po prostu jako fundament dla zasad w sferze pracy niewymagający już skrupulatnego wyjaśniania. Warto odwołać się tutaj do dokumentu, będącego wspólnym uzgodnieniem Kościołów katolickiego i ewangelickiego w Niemczech, zatytułowanego Demokracja potrzebuje cnót (Demokratie braucht Tugenden) z 2006 roku, w którym przedstawia się chrześcijańskie podejście społecznoetyczne w perspektywie bieżącej sytuacji społecznej i gospodarczej w Niemczech. Również w tym tekście nie znajdziemy bezpośredniego zdefiniowania pojęcia solidarności, jest ono za to ujmowane wraz ze sprawiedliwością, godnością człowieka oraz wolnością za kluczowy cel Kościoła w budowaniu porządku państwa i Kościoła. Solidarność jest również zadaniem dla Kościoła, demokracji i mass mediów, jest koniecznym spoiwem na poszczególnych etapach życia społecznego, począwszy od rodziny, przez grupy sąsiedzkie, towarzyskie i zawodowe, po społeczeństwo globalne ${ }^{19}$.

Wartość samostanowienia jest $\mathrm{w}$ kontekście sfery pracy rozumiana, zgodnie podkreślaną zwłaszcza w ostatnich latach tradycją, jako przynależąca do wspomnianej już kategorii wolności odpowiedzialnej. Wyprowadzana jest $\mathrm{z}$ fundamentalnych zasad antropologii luterańskiej; z rozumienia człowieka jako tkwiącego w dynamicznym napięciu pomiędzy samostanowieniem a odpowiedzialnością, z którego rozwija się chrześcijańska wolność. W memorandum Wolność cyfrowa. Dziesięć przykazań w czasie cyfrowej transformacji (Freiheit digital. Die Zehn Gebote in Zeiten des digitalen Wandelns), będącym bardzo pogłębionym studium nad rozumieniem chrześcijańskiego powołania i chrześcijańskich wartości w per-

${ }^{18}$ Evangelische Kirche in Deutschland, Solidarität und Selbstbestimmung..., dz. cyt., s. 49.

${ }_{19}$ Evangelische Kirche in Deutschland, Demokratie braucht Tugenden. Gemeinsames Wort des Rates der Evangelischen Kirche in Deutschland und der Deutschen Bischofskonferenz zur Zukunft unseres demokratischen Gemeinwesens, Hannover 2006, s. 22. 
spektywie rewolucji technologicznej, samostanowienie jest właśnie rozważane jako koniecznie przynależne do wolności odpowiedzialnej, która ustala właściwy stosunek pomiędzy prawem jednostki do decydowania o sobie a społecznym porządkiem. Przy czym nie chodzi tu o jakiś prosty wybór albo-albo. Wolność, którą został obdarzony człowiek, oznacza również wiedzę o konfliktach, ambiwalencjach i kompleksowości, które wynikają z powołania człowieka przez Boga do współkształtowania ziemskiej rzeczywistości ${ }^{20}$. Samostanowienie i wolność odpowiedzialna wymagają więc teologicznej refleksyjności.

Ta ogólna perspektywa odnoszona do wartości samostanowienia znajduje swoje uszczegółowienie w sferze pracy poprzez zestawienie jej ze społecznymi dopełnieniami: współpracą oraz bezpieczeństwem. Są one koniecznym warunkiem dla tego, aby praca była produktywna. Myśląc o produktywności, autorzy nie zawężają jej naturalnie do wąskiego znaczenia ekonomicznego, ale raczej odnoszą ją do biblijnej antropologii człowieka, który został powołany do bycia współpracownikiem Boga. Bezpieczeństwo i współpraca, wraz ze samostanowieniem $\mathrm{w}$ relacjach $\mathrm{w}$ przestrzeni pracy, tworzą konieczne ramy potencjału, w którym jednostka może realizować swoje zdolności i zarazem przyczyniać się do rozwoju społeczeństwa. Ujmując jeszcze inaczej, uzdalniają jednostkę do stawania się odpowiedzialnym podmiotem życia społecznego działającym w wolności i solidarności ${ }^{21}$.

Współpraca i bezpieczeństwo mogą być wobec siebie komplementarne, ale też i mogą wobec siebie pozostawać w konflikcie. Tak jest na przykład, kiedy wymogi bezpieczeństwa wdrażane przez instytucje ograniczają wolność albo gdy współpraca dla dobra czy to przedsiębiorstwa, czy wspólnoty, czy społeczeństwa zakłóca indywidualną inicjatywę. W konsekwencji więc teologowie podkreślają, że „dobra praca może się wyłonić wtedy, gdy relacje pomiędzy samostanowieniem, współpracą i bezpieczeństwem są właściwie zrównoważone"22. Zarazem jednak przyznają, że sytuacje konfliktowe, wynikające z niedostatecznej równowagi pomiędzy tymi wartościami i związane z nimi niezadowolenie, mają w sobie potencjał prowadzący do rozwoju i wyłaniania się nowych form lepiej odpowiadających okolicznościom.

Wartości solidarności i samookreślenia tworzą fundament dla konkretnych zasad, które zdaniem teologów powinny budować stosunki pracy na poziomie przedsiębiorstwa, instytucji i państwa, i które w konsekwencji adresowane są do osób odpowiedzialnych za politykę społeczną, do członków związków zawodowych oraz do pracodawców. Zasadą nadrzędną jest sprawiedliwe uczestnictwo

${ }^{20}$ Evangelische Kirche in Deutschland, Freiheit digital. Die Zehn Gebote in Zeiten des digitalen Wandels, Leipzig 2021, s. 49.

${ }^{21}$ Evangelische Kirche in Deutschland, Solidarität und Selbstbestimmung..., dz. cyt., s. 50.

${ }^{22}$ Tamże. 
w pracy zarobkowej gwarantującej wystarczający dochód; a zatem zarówno eliminowanie bezrobocia, jak i pomniejszanie zakresu pracy niepewnej (precarious) powinny być traktowane jako główny cel polityki społecznej.

Dążenie do sprawiedliwej i powszechnej pracy jest punktem wyjścia dla zasad szczegółowych. Ich katalog jest dość szeroki i, jeżeli można tak określić, otwarty. Treściowo są jednak spójne i zbieżne $\mathrm{z}$ ewangelicką wizją relacji między jednostką a społeczeństwem.

Po pierwsze więc, dobra praca musi zakładać wykorzystywanie i rozwijanie ludzkiej zdolności i kreatywności, stąd też z pracą nierozerwalnie jest związane szkolenie zawodowe, choć naturalnie cele edukacji nie zawierają się w przygotowaniu do wykonywania zawodu, jak stwierdza kolejne memorandum EKD:

Wykształcenie w ewangelickim rozumieniu powinno się przyczyniać do tego, aby każdy (mężczyzna) i każda (kobieta) mogli właściwie rozeznać się w świecie. Otwiera jednostki na dyskusję i na zrozumienie wartości oraz zawiera wewnątrz poznania różne wymiary ludzkiego życia ${ }^{23}$.

Po drugie, praca nie może być traktowana jako cel sam w sobie, ale jako środek do tworzenia towarów i usług wartościowych dla społeczeństwa jako całości. Po trzecie, przyjmując, że każda osoba powinna być ujmowana jako posiadająca potencjał do przyczyniania się do współpracy społecznej, konieczne jest szerokie rozumienie miejsca pracy. Dlatego też, z perspektywy całego nowoczesnego społeczeństwa, opierającego się przecież na podziale pracy, istotne jest refleksyjne i odbywające się na bieżąco regulowanie stosunków pracy zmieniających się w miarę postępu technologicznego, ekonomicznego i społecznego. Teologowie z EKD formułują tutaj szczegółowe polityczno-społeczne zalecenie:

Potrzebujemy zatem regulacji dla pracowników uczestniczących w asymetrycznych relacjach władzy. Aby unikać konfliktów, prawodawcy powinni regulować warunki, partnerzy negocjacji powinni zgadzać się na regulacje dotyczące poszczególnych branż, rady pracownicze i zawodowe powinny reprezentować interesy pracowników w przedsiębiorstwach, a przedsiębiorstwa podejmować odpowiedzialność w odniesieniu do ich pracowników i warunków w miejscach pracy $^{24}$.

Po czwarte, praca nie może jednak być ograniczana do pracy zarobkowej, co jest ciążącym i niezaprzeczalnym dziedzictwem uprzemysłowienia i pewnych

${ }^{23}$ Evangelische Kirche in Deutschland, Gute Schule aus evangelischer Sicht. Impulse für das Leben, Lehren und Lernen in der Schule, Hannover 2016, s. 4.

${ }^{24}$ Evangelische Kirche in Deutschland, Solidarität und Selbstbestimmung..., dz. cyt., s. 51. 
ideologii nowoczesności (zwłaszcza marksizmu). Praca zarobkowa nie byłaby zdolna spełniać swojej funkcji, gdyby nie opierała się na szerokim fundamencie pracy opiekuńczej, pracy w rodzinie, rodzicielstwa, różnych form wolontariatów czy działań na rzecz społeczeństwa obywatelskiego. Stąd też, po piąte, praca nie może być traktowana po prostu jako towar, inaczej mówiąc, nie może być komodyfikowana. Jest nierozerwalnie złączona $\mathrm{z}$ daną osobą, z jej wysiłkiem i jej twórczością, dlatego też musi być chroniona przez instytucje społeczeństwa.

Po szóste, wszyscy uczestnicy sfery pracy muszą mieć świadomość konfliktów, które są inherentne w dynamice procesów kształtujących pracę. Chrześcijańska wizja z pewnością nie może polegać na ich zbywaniu czy niedostrzeganiu, ale raczej ma kształtować kulturę negocjacji partnerów sfery pracy. Teologowie z EKD zwracają uwagę, że konflikty te mogą przenosić się na poziom międzynarodowy, w miarę jak postępuje ekonomiczna globalizacja, stąd też konieczny jest ciągły dialog z instytucjami społeczeństwa obywatelskiego, również z Kościołami. Wreszcie, po siódme, praca powinna być skierowana na przyszłość, to znaczy zarówno państwa, przedsiębiorstwa, związki zawodowe, jak i jednostki muszą uwzględniać charakter przyszłych aktywności, również po to, by właściwie gospodarować bieżącym wysiłkiem pracowników.

Jak już zaznaczono, powyższa lista nie jest ściśle sformułowana, jednak punkty w niej wymienione pokrywają zakres treściowy, który teologowie z EKD odnoszą do ewangelickiej wizji dobrej pracy. Zakres ten znajduje dobre podsumowanie w koncepcji wspomnianej wprawdzie mimochodem, ale łączącej w sobie poszczególne punkty teologicznego zdefiniowania pracy. Jest to idea rozwoju kultury pracy jako powołania, którą Kościoły oraz instytucje państwowe, społeczne oraz ekonomiczne powinny pielęgnować i rozwijać.

Kultura pracy jako powołania może być wyodrębniana i promowana jako pewna kategoria społecznoetyczna pomagająca upowszechniać takie podejścia do pracy, które będą właściwie (z chrześcijańskiego punktu widzenia) kształtować stosunki między jednostką, społeczeństwem, pracą i ekonomią. Potencjał tej kategorii odsłania się szczególnie wyraźnie, jeśliby przyjąć, za współczesnymi definicjami (Giddens, Castells, Mathews), że kultura jest zintegrowanym systemem norm, wartości, przekonań i wzorów kultury, że jest po prostu, jak stwierdza ostatni z wymienionych autorów, połączeniem ,idei kultury jako sposobu życia pewnego ludu z bardziej współczesną koncepcją kultury jako informacji i tożsamości dostępnych w globalnym supermarkecie kultury"25. Stwierdzenie Mathewsa odnosi się do współczesnych napięć pomiędzy tradycyjnymi systemami kulturowymi a tymi elementami, które są rezultatem procesów globalizacyjnych, ukazuje również współczesne możliwości wyboru (chociaż często pozornego) wartości i wzorów kultury. Takie napięcia dotyczą naturalnie rów-

${ }^{25}$ G. Mathews, Supermarket kultury, Warszawa 2005, s. 13. 
nież sfery pracy, w której następuje zderzenie między utrwalonymi przez dekady przekonaniami a nowymi sposobami myślenia powodowanymi zwłaszcza przez rewolucję technologiczną. Jest to przede wszystkim zderzenie między sztywnymi a elastycznymi stosunkami pracy, między hierarchicznością a sieciowością, między absolutyzacją pracy a jej instrumentalizacją. Zarówno z dotychczasowymi wzorami kultury pracy, jak i z wzorami wyłaniającymi się, wiążą się tak szanse, jak i zagrożenia. Kategoria kultury pracy jako powołania dobrze lokuje się pomiędzy nimi. Nadaje pracy właściwe znaczenie etyczne, zwracając uwagę, że wierne wypełnianie swoich obowiązków zawodowych należy do powołania człowieka. Podkreśla społeczny wymiar pracy, uświadamiając, że nie powinna być ona traktowana wyłącznie jako środek osiągnięcia sukcesu materialnego czy zawodowego, ale również jako uświadamiany osobisty wkład w dobro wspólne. Rozszerza zakres pracy $\mathrm{z}$ wąskiej perspektywy pracy zarobkowej do aktywności ludzkich realizowanych w sferze opiekuńczej, w rodzinie, czy też w społeczeństwie obywatelskim. Pokazuje twórczy wymiar pracy, w którym jest ona drogą do samorozwoju człowieka, również poprzez postawę otwartości na nabywanie nowych umiejętności i kompetencji, co w perspektywie postępu technologicznego jest szczególnie ważne. Chroni wreszcie przed postępującą atomizacją i rozkładem społeczeństwa będących również pochodnymi wpływu nowych technologii. Praca jako powołanie, ujmowana jako wartość kulturotwórcza, jest w ten sposób bardzo cennym instrumentem kształtowania społeczeństwa w kontekście gwałtownych przemian, które powodują erozję dotychczasowych fundamentów, na których było ono budowane.

\section{Streszczenie}

Artykuł ma na celu prezentację ewangelickiej koncepcji pracy w perspektywie wyłaniania się nowego porządku ekonomiczno-społecznego i tzw. czwartej rewolucji przemysłowej. Pokazuje, jak teologowie EKD adaptują reformacyjne nauczanie społeczne do bieżących okoliczności i dowodzi, że Kościół ewangelicki dostrzega potrzebę kształtowania systemowej koncepcji obejmującej zarówno modele stosunków pracy, jak i modele edukacji. Refleksja teologiczna EKD zmierza przede wszystkim do sformułowania aksjologicznego fundamentu, na którym mogą oprzeć się strategie polityczne czy społeczne. Przypomnienie teologicznego znaczenia pracy jako powołania jest ważnym czynnikiem tego fundamentu. Realizacja zamierzenia zakłada analizę wybranych tekstów Kościoła osadzoną w kontekście zwięzłego nakreślenia głównych punktów bieżących przemian technologicznych, ekonomicznych i społecznych.

\section{Stowa kluczowe}

praca, ewangelicki Kościół w Niemczech, protestantyzm, postęp technologiczny 


\section{Theological Interpretation of the Upheavals in the Area of Work. An Approach of the Evangelical Church in Germany}

\section{Summary}

The article presents the Evangelical teaching on work in light of the emergence of a new socioeconomic order, denoted as the fourth industrial revolution. It shows how the theologians from the Evangelical Church in Germany (EKD) adopt the social teaching of the Reformation to the current situation and discusses their systemic vision of relationships in work and education. Theological reflection of the EKD focuses on the axiological foundation for the political and social programs. The concept of work as vocation is a crucial component of it. The article examines selected Church documents in the wider context of descriptions of the current upheavals in technology, economy and society.

\section{Keywords}

work, Evangelical Church in Germany, Protestantism, technological progress

\section{Bibliografia}

Evangelische Kirche in Deutschland, Demokratie braucht Tugenden. Gemeinsames Wort des Rates der Evangelischen Kirche in Deutschland und der Deutschen Bischofskonferenz zur Zukunft unseres demokratischen Gemeinwesens, Hannover 2006.

Evangelische Kirche in Deutschland, Freiheit digital. Die Zehn Gebote in Zeiten des digitalen Wandels, Leipzig 2021.

Evangelische Kirche in Deutschland, Gute Schule aus evangelischer Sicht. Impulse für das Leben, Lehren und Lernen in der Schule, Hannover 2016.

Evangelische Kirche in Deutschland, Kirche der Freiheit. Perspektiven für die evangelische Kirche im 21. Jahrhundert. Ein Impulspapier des Rates der EKD, Hannover 2006.

Evangelische Kirche in Deutschland, Solidarität und Selbstbestimmung im Wandel der Arbeitswelt. Eine Denkschrift des Rates der Evangelischen Kirche in Deutschland (EKD) zu Arbeit, Sozialpartnerschaften und Gewerkschaften, Gütersloh 2015.

Evangelische Kirche in Deutschland, The World of Work 4.0, Hannover 2017.

Giddens A., Nowoczesność i tożsamość. „,Ja” i spoleczeństwo w epoce późnej nowoczesności, Warszawa 2012.

Luter M., Do chrześcijańskiej szlachty niemieckiego narodu o ulepszeniu chrześcijańskiego stanu, seria: „Z problemów reformacji”, t. 6, Bielsko-Biała 1993.

Luther M., Ein Sermon vom ehelichen Stand, w: Vom ehelichen Leben und andere Schriften über die Ehe, Hg. D. Lorenz, Ditzingen 1997.

Mathews G., Supermarket kultury, Warszawa 2005. 
Reuter H.-R., Grundlagen und Methoden der Ethik, w: Handbuch der Evangelischen Ethik, Hg. W. Huber, T. Meireis, H.-R. Reuter, München 2015.

Schwab K., The Fourth Industrial Revolution, Geneva 2016.

Szacki J., Historia myśli socjologicznej, t. 1, Warszawa 2012.

Weber M., Etyka protestancka a duch kapitalizmu, Lublin 1994. 